\title{
Efecte ale stilului de leadership asupra performantei în mediul organizational
}

\author{
Veronica - Stăvilă Rîlea ${ }^{1}$ \\ Universitatea Babeş-Bolyai, Cluj-Napoca
}

\begin{abstract}
Based on the transformative theory of leadership, the present research examines the predictive value of the process of Leadership on organisational citizenship behaviour, counterproductive work behaviour, and the performance of supervisors as it is perceived by subordinates. 138 subordinates form different organisations participated in this study. The participants were asked to complete several questionnaires: MLQ (Multifactor Leadership Questionnaire), OCBS (Organizational Citizenship Behaviour Scale), and IODS (Interpersonal and Organizational Deviance Scale).

The results indicate that leadership style predicts organizational citizenship behaviour and counterproductive work behaviour. Furthermore, leadership style was related to the performance, extra-effort, and satisfaction with supervisor.

The results support those of other researches in this field.
\end{abstract}

Keywords: Transformational, transactional and laissez-faire leadership, organizational counterproductive behavior organizational citizenship behavior, satisfaction with supervisor, performance, and extra-effort.

\section{Rezumat}

Bazându-se pe teoria leadershipul-ui transformațional; studiul de față investighează tipul de leadership ca predictor al performanței manifestată prin tipurile de comportamente la locul de muncă a 60 de manageri din mediul organizațional. Pentru evaluarea acestor leaderi au fost implicați în cercetare 138 de participanți subalterni ai acestor manageri. Acestora li s-au aplicat, pentru măsurarea predictorilor, chestionarul de personalitate BFQ şi chestionarul heteroevaluator a tipului de leadership MLQ (Multifactor Leadership Questionaire). Pentru măsurarea variabilelor criteriu s-au aplicat următoarele instrumente: IODS ce măsoară comportamentele contraproductive la locul de muncă, Scala CCO care evaluează comportamentul cetățenesc organizațional manifestat la locul de muncă, şi $M L Q$ prin intermediul căruia s-a evaluat efortul suplimentar depus de către subordonați, satisfacția cu managerul şi eficiența superiorului.

Rezultatele obținute în urma acestui studiu, indică faptul că comportamentelele prosociale sunt relaționate pozitiv cu un stil de leadership Transformațional şi negativ de stilul de leadership Laissez-Faire. Comportamentele contraproductive sunt asociate pozitiv cu un stil de leadership Laissez-Faire şi negativ cu Leadership-ul Transformațional. Conform rezultatelor obținute în studiul de față efectele leadershipului tranzacțional asupra comportamentelor prosociale şi deviante manifestate de către subalterni la locul de muncă sunt nesemnificative.

Cuvinte cheie: leadership transformațional, tranzacțional, laissez-faire, comportament contraproductiv, comportament cetățenesc organizațional, satisfacția cu superiorul, efort suplimentar şi eficiență.

Hogan \& Kaiser (2005) afirmă că procesul de leadership este probabil cea mai importantă problemă existentă în ştiințele umaniste. Acesta este procesul cu consecințele cele mai vaste şi hotărâtoare asupra organizațiilor, de el depinzând

\footnotetext{
${ }^{1}$ Adresa de corespondență: ralea24@yahoo.com
}

dezvoltarea, supraviețuirea sau dispariția unei organizații.

De competența unui leader depinde eficiența echipei de muncă în realizarea obiectivelor organizaționale, care are ca şi consecințe creşterea bunăstării tuturor celor implicați (Schaubroeck, Lam \& Cha, 2007, Chemers, 2000; Fuqua, \& Newman, 2005). 
Una dintre consecințele stilului de leadership este performanța profesională. Abordarea tradițională restrânge spațiul performanței organizaționale la ceea ce Borman şi Motowidlo (1997) numeau performanță în sarcină, definită ca eficiența cu care deținătorii posturilor de muncă realizează activitățile ce contribuie la componenta tehnică de bază a organizației.

Deşi este larg recunoscut faptul că performanța în muncă este multidimensională, doar recent în literatura de specialitate a fost recunoscut rolul comportamentelor angajaților care nu se integrează în dimensiunea performanței în sarcină, de exemplu, comportamentele cetățeneşti organizaționale şi cele deviante (Dalal, 2005). Borman şi Motowidlo (1997) au argumentat că acest tip de comportamente sunt importante deoarece conturează contextul organizațional, social şi psihologic servind drept catalizator pentru sarcinile şi procesele de muncă. Unii autori (Rotundo \& Sackett, 2002, Viswesvaran \& Ones, 2000) sugerează existența a trei domenii largi de performanță: performanța în sarcină, comportamentul cetățenesc (CCO), comportamentul contraproductiv (CCp).

În această ordine de idei, rezultatele studiilor pe tematica performanță şi leadership sunt diverse. Ca o sinteză a studiilor realizate, s-a constatat că tipul de leadership are un rol hotărâtor asupra performanțelor şi dezvoltării organizaționale atât prin prisma unor criterii obiective (realizarea sarcinilor şi activităților) (Liao \& Chuang, 2007; Bono et al., 2007; Schaubroeck et al., 2007; Howell, \& Avolio, 1993), cât şi a unora subiective cum ar fi: satisfacția cu munca, climatul organizațional sau calitatea relațiilor dintre subalterni (Arnold, et al., 2007; Dierendonck, et al., 2005; Epitropacki \& Martin, 2005; Sy, et al., 2005), relația acestora cu leaderul (Offerman, \& Hellman, 1996; Bono \& Judge, 2004; Bass, et al., 2003), absenteism, fluctuație, comportamente contraproductive organizaționale $(\mathrm{CCpO})$, comportamentelor cetățeneşti organizaționale (CCO) (McCarthy Veach, 2001; Pearce \& Sims, 2002).

Studiul de față are la bază teoria transformațională a leadershipului. Ca urmare vom face o scurtă caracterizare a acesteia. În plus, dat fiind faptul în acest studiu urmărim să testăm legătura cauzală dintre stilul de leadership şi CCO, CCp, Satisfacția cu Leaderul (SatL), Efortul suplimentar (ES) şi Eficiența superiorului (Ef), se va realiza o scurtă prezentare a acestora, apoi se vor specifica ipotezele de cercetare şi modul de testare a acestora, după care se va trece la analiza şi discutarea rezultatelor obținute.

Deşi s-au realizat cercetări ce au relaționat supervizarea cu CCO şi CCp (McCarthy Veach, 2001), practic nu există studii care să fi relaționat modul în care teoria transformațională are 0 valoare predictivă asupra acestor comportamente.

\section{Scurtă descriere a teoriei transformaționale}

Teoria transformațională este structurată pe trei stiluri de leadership: Leadership Tranzacțional, Transformațional şi Laissez-Faire (sau absența procesului de leadership). Leadershipul transformațional încorporează dimensiunile celui tranzacțional. $\mathrm{Ca}$ urmare un leader eficient este cel ce poate integra în stilul său de conducere ambele tipuri (Avolio \& Bass, 1999).

Bass, Jung, Avolio, Berson, (2003) definesc leadershipul tranzacțional $(L T z)$ ca un stil ce identifică trebuințele subalternilor pentru a le satisface în schimbul performanțelor obținute în sarcini. În contrast, leadeshipul de tip transformațional (LTf), merge ceva mai departe de această relație de schimb dintre leader şi subaltern. LTf inspiră subordonații pentru a-şi transcede propriile interese şi percepții vizavi de limitele personale, cu scopul de a urmări realizarea obiectivelor comune benefice organizației şi colectivului. Acesta furnizează subalternilor o viziune clară asupra viitorului, forțând oarecum identificarea acestora cu organizația, dezvoltându-i pe plan profesional şi stimulându-i intelectual pentru a aborda soluții multiple inovative la problemele ce apar în decursul realizării muncii (Kara et al., 2007; Schaubroeck et al., 2007; Bycio, Hacket, Allen, 1995, Den Hartog et al., 1997 ; Kark, et al., 2003).

Leadership-ul

cuprinde 4 componente:

transformațional

Influența idealizată se referă la leaderii care sunt văzuți de către angajați ca fiind modele, ca urmare subordonații se identifică cu aceştia.

Motivația Inspirațională manifestarea de expectanțe mari față de angajați şi motivarea acestora pentru a deveni mai implicați în sarcinile pe care le au de îndeplinit.

Stimularea intelectuală se referă la comportamente din partea superiorului care stimulează angajații să devină creativi şi inventivi, în sensul că acesta sprijină intențiile subordonaților atunci când vor să încerce noi 
direcții de abordare a problemelor (Northouse, 2001; Keller, 2006; Kelloway, et al., 2006).

$$
\text { Considerația individualizată }
$$

presupune oferirea unui climat suportiv şi atenție la problemele şi necesităților angajaților. De exemplu, managerii pot folosi delegarea responsabilităților pentru subordonații care au nevoia accentuată de actualizare (motivație de autorealizare) (Kark, et al., 2003).

$$
\begin{aligned}
& \text { Componentele leadershipului } \\
& \text { tranzacțional }(L T z) \text { : }
\end{aligned}
$$

Recompensa contingentă presupune ca leaderul să ofere recompense corecte şi adecvate subalternilor în schimbul realizării sarcinilor la nivelul standardelor aşteptate.

Management prin excepție activ implică monitorizarea performanței subordonaților şi luarea de măsuri corective în cazul apariției neregulilor, precum şi anticiparea deviațiilor posibile de la standardele acceptate (Bono, \& Judge, 2004).

Management prin excepție pasiv se referă la un comportament ce are scopul de a interveni când deja au apărut probleme, oferind feedback negativ şi pedepse.

Stilul de leadership Laizez - faire (LLf), se caracterizează prin evitarea responsabilităților şi obligațiilor precum şi eşecul de a exercita ambele tipuri de leadership: tranzacțional şi transformațional (Sosik, Avolio \& Kahai, 1997; Northouse, 2001).

Referitor la validitatea teoriei transformaționale, unii autori au găsit 8 dimensiuni ale leadershipului tranzacțional şi transformațional, în timp ce alți cercetători au afirmat că ar exista doar 6 , trei dimensiuni aparținând celui tranzacțional iar celelalte trei, celui transformațional (Avolio şi Bass, 1999). Avolio şi Bass (1999) au afirmat că există un model în 6 factori, în loc de 8: astfel motivația inspirațională şi influența idealizată sunt combinate într-un singur factor, stimularea intelectuală, considerație individualizată, recompensa contingentă, managementul prin excepție activ, iar managementul prin excepție pasiv - şi tipul laissez-faire sunt unul şi acelaşi factor. El a susținut că acest model în doar 6 factori ar reprezenta mai bine structura leadershipului transformațional şi tranzacțional.

In plus, factorii încadrați la tipul transformațional au obținut o validitate mai mare decât cei corespunzători tipului tranzacțional, unde cel mai bun coieficient de validitate a obținut-o factorul recompensă contingentă (.40). Lowe et al. (1996) au raportat o corelație între dimensiunile leadershipului transformational de peste 0,70 (citat în: Bono, \& Judge, 2004)

Intr-o metaanali realizată de Judge \& Piccolo (2004), rezultatele arată că leadershipul transformațional are o validitate generală de .44, recompensa contingentă a leadershipului tranzacțional - (.39), iar celelalte două componente $\mathrm{s}$-au dovedit instabile în a prezice criteriile: performanță, satisfacția cu munca, satisfacția cu superiorul (Judge \& Piccolo, 2004). În plus, s-au găsit corelații de 0.80 între leadershipul transformațional şi cel tranzacțional. Leadershipul laissez - faire a obținut o corelație negativă cu celelalte două tipuri (-0.37 cu $L T z$ şi -.65 cu $L T f$ ). Corelațiile obținute pe celelalte 2 componente ale leadershipului tranzacțional au demonstrat 0 validitate relativ scăzută (sub 0.30 ) (Judge, \& Piccolo, 2004; Judge et al., 2004).

Autorii au mai constatat că validitatea teoriei transformaționale este influențată de design-ul cercetării şi de sursele datelor. Acestea au o validitate mai mare în design-uri transversale decât în cele longitudinale. Validitatea leadershipul-ui transformațional pare a se generaliza de-a lungul diferitor situații; evaluările realizate în medii de afaceri, în învățământ, în sectorul militar şi public, nu au dus la diferențe la semnificative. În ceea ce priveşte validitatea componentei leadershipului tranzacțional - recompensa contingentă, s-au obținut următorii coieficienți de validitate: mediu de afaceri (.51), învățământ (.19), mediul militar (.32), şi sectorul public (.27) (Judge \& Piccolo, 2004; Judge, Piccolo, \& llies, 2004).

\section{Comportament cetățenesc organizațional (CCO) şi comportament contraproductiv (CCp)}

Comportamentul contraproductiv a fost definit ca şi comportamente intenționate (şi nu accidentale) care au consecințe dăunătoare atât asupra organizațiilor cât şi asupra persoanelor implicate, indiferent dacă ne referim la angajați, clienți sau manageri (Dalal, 2005; Spector \& Fox, 2002; Rotundo \& Sackett, 2002). Acestea au fost diferențiate de către autori în CCp orientate asupra indivizilor din mediul organizațional (CCp-I) şi comportamente dăunătoare orientate asupra organizației (CCp-O) (Levine et al., 2005).

Până în prezent, există puține studii asupra relației dintre leadership şi $\mathrm{CCpO}$, iar cele realizate au fost derulate în mediul organizațional educațional sau clinic şi mai 
puțin cel industrial (McCarthy Veach, 2001; Cobia \& Boes, 2000).

$\mathrm{CCpO}$ a fost relaționat cu diferiți factori cauză, ca eventuale conflicte cu superiori, colegi (Bruk-Lee \& Spector, 2006), abilități cognitive (Dilchert, et al., 2007), factori de personalitate (Salgado, 2002), stres şi satisfacția cu munca (Colbert, et al., 2004; Hurz, \& Donovan, 2000).

CCO sunt comportamente intenționate şi discrete manifestate la locul de muncă care au efecte pozitive asupra organizației şi asupra membrilor acesteia, acestea nu sunt recompensate de către manageri deoarece nu intră în atribuțiile sarcinilor de muncă ale subalternilor. Există două tipuri de $\mathrm{CCO}$, cele de ajutor (CCO-A) şi cele de exprimare (CCO-E).

Cercetările au indicat că angajații care sunt satisfăcuți cu munca lor, consideră că sunt tratați corect de organizație şi beneficiază de mai multă autonomie în îndeplinirea sarcinilor de muncă, sunt mai predispuşi să se implice în astfel de comportamente (Moorman, 1991; Tepper, Lockhart \& Hoobler, 2001; Bachrach, Powell, Bendoly, Richey, 2006). In plus, alte cercetări au indicat că angajații implicați în sarcini care le aduc satisfacții şi sunt conduşi de lideri transformaționali şi suportivi sunt de asemenea predispuşi să manifeste CCO (Podsakoff, MacKenzie, Paine \& Bachrach, 2000). Între motivațiile care stau la baza CCO se remarcă şi valorile prosociale, preocupările legate de organizație şi managementul impresiei (Rioux \& Penner, 2001), factorii de personalitate (Salgado, 2002) şi abilitățile cognitive (Dilchert, Ones, Davis, Rostow, 2007), etc.

\section{Efortul suplimentar (ES)}

$E S$ ca efect al unui leadership eficient, este acea dorință a subordonaților de a realiza o performanță superioară prin eforturi mult mai mari, fiind convinşi să facă mai mult decât se poate aştepta în mod legitim de la ei. Leaderii cu scoruri mari la această scală amplifică dorința celorlalți de a reuşi şi cresc disponibilitatea acestora de a se strădui mai mult. (Avolio et al., 2007; Sîntion \& Iliescu, 2007).

\section{Eficiența (EF)}

Scala de Ef identifică prin scorurile ei înalte leaderii eficienți, judecați astfel prin prisma satisfacerii nevoilor profesionale ale celorlalți, a reprezentării grupului lor în fața unei autorități superioare, în satisfacerea cerințelor organizaționale şi, nu în ultimul rând, prin eficiența întregului grup coordonat. (Avolio et al., 2007; Sîntion \& lliescu, 2007).

\section{(SatL) \\ Satisfacția legată de leadership}

Scala de SatL conține doar doi itemi şi identifică prin scorurile sale înalte leaderi care generează satisfacție interpersonală în interactiunea cu ceilalți. Aceşti leaderi sunt persoane deschise, autentice, calde şi oneste, capabili să genereze şi să dezvolte sentimente de mulțumire la nivelul celor cu care lucrează (Avolio et al., 2007; Sîntion \& lliescu, 2007).

Studiul de față are ca scop testarea măsurii în care stilul de leadership manifestat de către manageri prezice comportamentele contraproductive, comportamentele cetățeneşti organizaționale, satisfacția cu managerul, disponibilitatea angajaților de a depune efort suplimentar în realizarea sarcinilor, precum şi măsura în care superiorul este perceput ca fiind eficient în atingerea obiectivelor organizaționale.

\section{Ipoteze de cercetare:}

1. a. LTf manifestat de către superior prezice în sens negativ CCp.

b. LTz manifestat de către superiori prezice în sens negativ rata de manifestării $C C p$.

c. Manifestarea unui stil LLf prezice scoruri înalte la $C C p$.

2. a. Un scor înalt la scala $L T f$ prezice în sens pozitiv manifestarea $\mathrm{CCO}$.

b. Manifestarea $L T z$ de către superior prezice în sens pozitiv apariția $C C O$.

c. LLf manifestat de către manager are impact negativ asupra manifestării $\mathrm{CCO}$ din partea subalternilor.

3.Subalternii ce percep managerii ca manifestând $L T f$ sunt mai predispuşi în a depune ES în realizarea sarcinilor, decât în cazul celorlalte două tipuri de leadership.

4. Angajații ce beneficiază de LTf sunt mai satisfăcuți cu managerul decât subalternii managerilor ce manifestă predominant celelalte tipuri de leadership.

5.Managerii care manifestă comportamente predominant de tip transformațional sunt percepuți de către subalterni ca fiind mai eficienți în comparație cu cei ce manifestă predominant LTz sau LLf. 


\section{Metodă}

\section{Participanți}

În cercetarea de față au fost incluşi 141 de voluntari angajați în organizații din sectorul public şi privat (10 organizații), dintre care $54,3 \%$ dintre participanți sunt femei şi 45,7\% bărbați. Media de vârstă este de 37.53 ani $(A S=11,88)$. Majoritatea participanților la cercetare au studii superioare - 65\%, 20\% studii medii şi $15 \%$ au absolvit doar gimnaziul. Rata răspunsurilor la chestionare a fost de 98\% (138).

\section{Instrumente}

Chestionarul de personalitate BFQ (Big Five Questionnaire) este alcătuit din 5 mari scale ce evaluează cinci factori generali: Extraversie, Agreabilitate, Conştiinciozitate, Neuroticism, Deschidere spre experiență. Acesta cuprinde 156 itemi şi a fost adaptat pe populația românească (Caprara et al., 2008).

MLQ (Multifactor Leadership Questionaire) Chestionarul este tradus şi adaptat pe populația românească şi este compus din 45 itemi, grupați în 12 scale. Primele 9 scale evaluează stilul de leadership, celelalte trei au rolul de a diferenția leaderii eficienți ce cei mai puțin eficienți (Avolio et al., 2007, Sîntion \& Iliescu, 2007).

Scalele MLQ: LTf cu subscalele: Influență idealizată, Motivație inspirațională, Stimulare intelectuală, Considerație individualizată.

Leadershipul $\quad L T z: \quad$ subscala Recompensă contingentă, Management prin excepție activ, Management prin excepție pasiv şi scala LLf.

Scalele ce reflectă rezultatele tipului de leadership sunt: Scala ES, Ef şi SatL.

Pentru măsurarea Comportamentelor Cetățeneşti Organizaționale $\mathrm{s}-\mathrm{a}$ utilizat chestionarul OCBS (Organizational Citizenship Behavior Scale) dezvoltat de către Van Dyne \& LePine (1998). Acesta conține 2 scale: scala "ajutor" (CCOS-A), care cuprinde 7 itemi şi cea de "exprimare" (CCOS-E) alcătuită din 6 itemi.

Pentru măsurarea Comportamentelor Contraproductive s-a utilizat IODS (Interpersonal and Organizational Deviance Scale) chestionarul a fost elaborat de către Bennett \& Robinson (2000) şi conține 19 itemi. Participanților li se cere să evalueze pe o scală Likert de 7 puncte, măsura în care se angajează într-o serie de CCp, primii 7 itemi măsoară CCp orientat asupra individului (CCpI) din organizație, ceilalți 12 itemi evaluează manifestarea comportamentelor CCp orientate asupra organizației (CCp-O).

\section{Procedură}

Aplicarea instrumentelor $s$-a făcut individual pentru chestionarul BFQ şi colectiv (câte 3 sau 4 persoane) pentru MLQ, IODS, şi OCB. Participanții au fost asigurați în prealabil că răspunsurile la chestionare sunt strict confidențiale, de asemenea, li s-a sugerat ca în loc de nume să specifice un număr sau un semn după care să-şi poată identifica ulterior rezultatele.

Ca o mențiune specială, în cazul aplicării MLQ fiecare manager a fost evaluat de către 3 sau 4 subalterni, pe o scală de la 0 la 4, unde 0 înseamnă absența totală al unui tip de comportament manifestat de către superior, 4 însemnând manifestarea de zi cu zi a unui anumit comportament.

Metoda statistică utilizată pentru testarea ipotezelor a fost regresia multiliniară ierarhică. Motivul alegerii acestei metode este controlul şi evitarea erorii de specificare (Sava, 2004), deoarece numeroase studii au demonstrat o influență definitorie a factorilor de personalitate asupra comportamentelor deviante şi prosociale (Jackson \& LePine, 2003; Colbert, et al., 2004; Salgado, 2002, etc.). Factorii de personalitate introduşi sunt: Agreabilitate $(\mathrm{Ag})$, Conştiinciozitate (Cs) şi Stabilitate Emoțională (StEm). Criteriul după care $\mathrm{s}$-au ales aceşti factori a fost corelațiile înalte şi semnificative ale acestora cu variabilele criteriu.

\section{Rezultate}

\section{Statistici descriptive}

In tabelul 1 , sunt prezentați indicatorii tendinței centrale, indicatorii de oblicitate şi boltire, coieficienții de consistență internă şi coieficienții de corelație dintre variabilele predictor (Leadership şi Personalitate) şi criterii (CCO şi CCp, ES, Ef şi SatL).

$\mathrm{Pe}$ baza rezultatelor prezentate în tabelul 1, coeficienții de consistență internă iau valori ce se încadrează în limitele general admise. Corelațiile dintre scalele predictor şi criteriu sunt semnificative, mai puțin cazul relației dintre predictorul LTz şi criteriile CCO-A şi CCO-E, precum şi relația dintre scala CCOE şi factorul de personalitate - StEm, unde corelațiile sunt nesemnificative. 
Tabel 1. Rezumat statistic al variabilelor incluse în studiu

\begin{tabular}{|c|c|c|c|c|c|c|c|c|c|c|c|c|c|}
\hline & 1 & 2 & 3 & 4 & 5 & 6 & 7 & 8 & 9 & 10 & 11 & 12 & 13 \\
\hline $1 \mathrm{LTf}$ & $(.86)$ & & & & & & & & & & & & \\
\hline $2 \mathrm{LTz}$ & $.48^{\star \star}$ & $(.53)$ & & & & & & & & & & & \\
\hline 3 LLF & $-.68^{\star *}$ & -.08 & $(.74)$ & & & & & & & & & & \\
\hline 4 CCO-A & $.28^{\star \star}$ & .12 & $-.20^{\star}$ & (.78) & & & & & & & & & \\
\hline 5 CCO-E & .14 & .14 & -.12 & $.43^{* *}$ & $(.76)$ & & & & & & & & \\
\hline $6 \mathrm{CCp}-1$ & $-.40^{\star *}$ & $-.18^{*}$ & $-.34^{* *}$ & $-.30^{\star \star}$ & $-.23^{\star *}$ & $(.80)$ & & & & & & & \\
\hline $7 \mathrm{CCp}-\mathrm{O}$ & $-.48^{* *}$ & -.11 & $-.44^{* *}$ & $-.37^{* *}$ & $-.25^{\star *}$ & $.65^{\star \star}$ & $(.87)$ & & & & & & \\
\hline $8 \mathrm{ES}$ & $.80^{* *}$ & $.31^{* *}$ & $-.60^{* *}$ & $.35^{\star *}$ & .16 & $-.32^{* *}$ & $-.36^{\star *}$ & $(.83)$ & & & & & \\
\hline $9 \mathrm{Ef}$ & $.85^{* *}$ & $.41^{* *}$ & $-.67^{\star *}$ & $.31^{\star *}$ & $.17^{*}$ & $-.41^{* *}$ & $-.40^{* *}$ & $.80^{* *}$ & $(.84)$ & & & & \\
\hline 10 SatL & $.75^{\star \star}$ & $.32^{\star \star}$ & $-.62^{\star *}$ & $.20^{*}$ & $.20^{*}$ & $-.38^{\star *}$ & $-.36^{\star *}$ & $.76^{\star *}$ & $.80^{\star *}$ & (.73) & & & \\
\hline $11 \mathrm{Ag}$ & $.40^{\star \star}$ & $.16^{\star}$ & $-.42^{\star *}$ & $.38^{* *}$ & $.34^{\star *}$ & $-.33^{\star *}$ & $-.32^{\star *}$ & $.44^{* *}$ & $.50^{\star \star}$ & $.43^{\star *}$ & (.73) & & \\
\hline $12 \mathrm{Cs}$ & $.42^{* *}$ & .08 & $-.43^{\star *}$ & $.20^{*}$ & $.30^{\star *}$ & $-.36^{\star *}$ & $-.39^{\star *}$ & $.39^{\star *}$ & $.48^{\star *}$ & $.44^{\star *}$ & $.48^{\star *}$ & $(.81)$ & \\
\hline $13 \mathrm{StEm}$ & $.28^{* *}$ & .00 & $-.28^{\star *}$ & $.30^{\star *}$ & .15 & $-.47^{\star *}$ & $-.44^{\star *}$ & $.24^{\star *}$ & $.28^{\star *}$ & $.19^{\star \star}$ & $.18^{*}$ & $.32^{\star *}$ & $(.90)$ \\
\hline Media & 45.3 & 27.2 & 3.77 & 35.28 & 28.39 & 15.09 & 25.34 & 8.39 & 11.83 & 5.74 & 139.7 & 84.3 & 149.4 \\
\hline AS & 10.03 & 5.6 & 3.2 & 6.1 & 6.56 & 6.63 & 12.38 & 2.72 & 3.41 & 1.97 & 12.2 & 7.84 & 22.82 \\
\hline
\end{tabular}

Tabel 2. Estimarea CCp pe baza predictorului Leadership.

\begin{tabular}{|c|c|c|c|c|c|c|c|c|}
\hline & \multicolumn{4}{|c|}{ LTf şi CCO-A } & \multicolumn{4}{|c|}{ LTf şi CCO-E } \\
\hline & $\mathbf{R}^{2}$ & $\Delta \mathbf{R}^{2}$ & $\beta$ & F schimbare & $\mathbf{R}^{2}$ & $\Delta \mathbf{R}^{2}$ & $\beta$ & F schimbare \\
\hline $\begin{array}{l}\text { Pasul I } \\
\mathrm{Ag} \\
\mathrm{Cs} \\
\text { StEm }\end{array}$ & $.18^{* *}$ & $.18^{\star \star}$ & $\begin{array}{l}.34^{*} \\
-.03 \\
.23^{* *}\end{array}$ & $F(3,135)=10,07 ; p<.00$ & $.10^{* *}$ & $.10^{* *}$ & $\begin{array}{l}.24^{*} \\
.03 \\
.00 \\
\end{array}$ & $F(3,135)=4.9 ; p<.05$ \\
\hline $\begin{array}{l}\text { Pasul II } \\
\text { Ag } \\
\text { Cs } \\
\text { StEm } \\
\text { LTf }\end{array}$ & $.22^{* *}$ & $.04^{*}$ & $\begin{array}{l}.31^{* *} \\
-.05 \\
.22^{* *} \\
.167^{*}\end{array}$ & 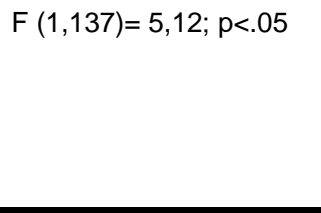 & $.14^{* *}$ & $.04^{*}$ & $\begin{array}{l}.25^{\star *} \\
.05 \\
.00 \\
.166^{\star}\end{array}$ & $F(1,137)=2,04 ; p<.05$ \\
\hline LTf & \multicolumn{4}{|c|}{ LTz şi CCO-A } & \multicolumn{4}{|c|}{ LTz şi CCO-E } \\
\hline $\begin{array}{l}\text { Pasul II } \\
\text { Ag } \\
\text { Cs } \\
\text { StEm } \\
\text { LTz }\end{array}$ & $.18^{\star *}$ & .004 & $\begin{array}{l}.33^{* *} \\
-.03 \\
.23^{\star *} \\
.06 \\
\end{array}$ & $F(1,137)=0,58 ; p>.05$ & $.11^{* *}$ & .01 & $\begin{array}{l}.10 \\
.24^{\star} \\
.003 \\
.10\end{array}$ & $F(1,137)=1.45 ; p>.05$ \\
\hline \multirow{2}{*}{ LTz } & \multicolumn{4}{|c|}{ LLF şi CCO-A } & \multicolumn{4}{|c|}{ LLF şi CCO-E } \\
\hline & $\mathbf{R}^{2}$ & $\Delta \mathbf{R}^{2}$ & $\beta$ & F schimbare & $\mathbf{R}^{2}$ & $\Delta \mathbf{R}^{2}$ & $\boldsymbol{\beta}$ & F schimbare \\
\hline $\begin{array}{l}\text { Pasul II } \\
\text { Ag } \\
\text { Cs } \\
\text { StEm } \\
\text { LLf }\end{array}$ & $.18^{* *}$ & .00 & $\begin{array}{l}.34^{* *} \\
-.03 \\
.23^{* *} \\
.003\end{array}$ & $F(1,137)=0,01 ; p>.05$ & $.12^{* *}$ & $.02^{*}$ & $\begin{array}{l}.12 \\
.25^{\star \star} \\
.00 \\
.05\end{array}$ & $F(1,137)=0,35 ; p>.05$ \\
\hline
\end{tabular}

Interpretarea rezultatelor prin intermediul modelelor de regresie multiliniară ierarhică

In primul pas al modelelor de regresie au fost introduşi cei trei factori de personalitate Cs, StEm, şi Ag, cu scopul, după cum am mai specificat mai sus, de a controla efectele acestora asupra variabilelor criteriu CCO şi $\mathrm{CCp}$, În pasul doi al modelelor de regresie au fost introduşi pe rând predictorii LTf, LTz şi LLf (tabelul 2). 
În modelele de regresie de mai jos putem observa că factorul personalitate explică într-adevăr într-o mare măsură evoluția criteriului CCp (tabel 2). Mai precis, CCp-I este explicat de către $\mathrm{Ag}$ şi StEm în proporție de $30 \%$ (StEm : $\beta=-0.39, p<.01$ şi $A g: \beta=-0.20$, $p<.05)$, şi respectiv aceştia din urmă explică $28 \%$ din evoluția CCp-O (StEm: $\beta=-0.35, p<.01$ şi $A g: \beta=-0.17, p<.05)$.

În pasul doi al modelului, se observă că dintre factorii incluşi în model, cei ce păstrează nivelul de semnificație sunt StEm şi Ag. Aceştia cu mici excepții, au un impact semnificativ asupra explicării CCp în ambele cazuri (tabel 2).

Prin introducerea LTf obținem un plus de predicție semnificativ al CCp-I cu $7 \%$ $\left(\Delta R^{2}=0,07, \quad p<.01\right)$ şi de $8 \%$ al CCp-O $\left(\Delta R^{2}=.08, p<.01\right)$. Ca dovadă, $F$ schimbare în ambele cazuri este semnificativ statistic ( $F$ $(1,137)=7,06 ; p<.01 ;$ respectiv $F(1,137)=$ 8.06, $\mathrm{p}<.01)$.

În consecintă, LTf are un rol semnificativ în prezicerea manifestării $C C p$ ( $\beta=-.27, p<.01$, în cazul CCp-I, şi $\beta=-.35, p<.01$ în cazul CCp-O). Ca urmare rezultatele din tabelul 2 confirmă ipoteza 1.a.

În pasul doi am modelului de regresie ce are ca scop testarea predicției factorului
LTz, observăm că acesta aduce un plus de explicare, a evoluției criteriului cu 5\% $\left(\Delta \mathrm{R}^{2}=.05, \mathrm{p}<.05\right), F$ schimbare $(F(1,137)=$ 5.06 , este semnificativ statistic la $p<.05$. Semnul minus al lui $\beta(-.17, p<.05)$ ne indică faptul că LTz are o influență negativă asupra CCp-I.

În cazul CCp-O, LTz are o valoare predictivă nesemnificativă asupra acestuia $\left(\Delta R^{2}=.02, p>.05 ; \beta=-.08, p>.05\right)$

Ca urmare, factorul LTz are un impact semnificativ asupra CCp-I şi nesemnificativ asupra CCp-O. Aceste rezultate confirmă parțial ipoteza 1.b, conform căreia un manager ce manifestă comportamente specifice LTz descurajează manifestarea de către subordonați a CCp de ambele tipuri (CCp-I şi CCp-O).

Vizavi de predictorul LLf şi criteriul CCp, predictorul prezice semnificativ evoluția CCp, acesta explicând $5 \%$ din variabilitatea CCp-I $\left(\Delta R^{2}=.05 ; F\right.$ schimbare $(1,137)$ este 5,12 , semnificativ la $p<.05$; iar $\beta=.171, p<.05$ ) şi respectiv $6 \%$ din cea a CCp-O $\left(\Delta \mathrm{R}^{2}=.06\right.$, $\mathrm{p}<.00$; iar $\beta=.28, \mathrm{p}<.00$ ) (tabelul 2).

Ca urmare ipoteza ştiințifică 1.c. va fi acceptată.

Tabel 3. Estimarea CCO pe baza predictorului Leadership

\begin{tabular}{|c|c|c|c|c|c|c|c|c|}
\hline & \multicolumn{4}{|c|}{ LTf şi CCO-A } & \multicolumn{4}{|c|}{ LTf şi CCO-E } \\
\hline & $\mathbf{R}^{2}$ & $\Delta \mathbf{R}^{2}$ & $\beta$ & F schimbare & $\mathbf{R}^{2}$ & $\Delta \mathbf{R}^{2}$ & $\beta$ & F schimbare \\
\hline $\begin{array}{l}\text { Pasul I } \\
\mathrm{Ag} \\
\mathrm{Cs} \\
\mathrm{StEm}\end{array}$ & $.18^{* *}$ & $.18^{* *}$ & $\begin{array}{l}.34^{*} \\
-.03 \\
.23^{* *}\end{array}$ & $F(3,135)=10,07 ; p<.00$ & $.10^{* *}$ & $.10^{\star *}$ & $\begin{array}{l}.24^{*} \\
.03 \\
.00\end{array}$ & $F(3,135)=4.9 ; p<.05$ \\
\hline $\begin{array}{l}\text { Pasul II } \\
\text { Ag } \\
\text { Cs } \\
\text { StEm } \\
\text { LTf }\end{array}$ & $.22^{\star *}$ & $.04^{\star}$ & $\begin{array}{l}.31^{\star *} \\
-.05^{\star} \\
.22^{\star *} \\
.167^{\star}\end{array}$ & $F(1,137)=5,12 ; p<.05$ & $.14^{* *}$ & $.04^{*}$ & $\begin{array}{l}.25^{\star \star} \\
.05 \\
.00 \\
.166^{\star}\end{array}$ & $F(1,137)=2,04 ; p<.05$ \\
\hline & \multicolumn{4}{|c|}{ LTz și CCO-A } & \multicolumn{4}{|c|}{ LTz și CCO-E } \\
\hline $\begin{array}{l}\text { Pasul II } \\
\mathrm{Ag} \\
\mathrm{Cs} \\
\text { StEm } \\
\text { LTz }\end{array}$ & $.18^{* *}$ & .004 & $\begin{array}{l}.33^{* \star} \\
-.03^{\star 2} \\
.23^{\star \star} \\
.06\end{array}$ & $F(1,137)=0,58 ; p>.05$ & $.11^{* *}$ & .01 & $\begin{array}{l}.10 \\
.24^{*} \\
.003 \\
.10\end{array}$ & $F(1,137)=1.45 ; p>.05$ \\
\hline & \multicolumn{4}{|c|}{ LLF şi CCO-A } & \multicolumn{4}{|c|}{ LLF şi CCO-E } \\
\hline & $\mathbf{R}^{2}$ & $\Delta \mathbf{R}^{2}$ & $\beta$ & F schimbare & $\mathbf{R}^{2}$ & $\Delta \mathbf{R}^{2}$ & $\beta$ & e F schimbare \\
\hline $\begin{array}{l}\text { Pasul II } \\
\mathrm{Ag} \\
\mathrm{Cs} \\
\mathrm{StEm} \\
\text { LLf }\end{array}$ & $.18^{* \star}$ & .00 & $\begin{array}{l}.34^{\star *} \\
.03 \\
.23^{\star *} \\
.003\end{array}$ & $F(1,137)=0,01 ; p>.05$ & $.12^{\star \star}$ & $.02^{*}$ & $\begin{array}{l}.12 \\
.25^{\star \star} \\
.00 \\
.05\end{array}$ & $F(1,137)=0,35 ; p>.05$ \\
\hline
\end{tabular}


În tabelul 3 s-a analizat măsura în care predictorul leadership prezice $\mathrm{CCO}$. In primul pas al modelului de regresie, ca şi anterior, au fost introduşi factorii de personalitate, după care au fost introduşi pe rând predictorii LTf, LTz şi LLf.

Factorii de personalitate au o influență semnificativă asupra $\mathrm{CCO}$, putem vedea că şi în pasul doi aceştia (sau cel puțin doi dintre aceştia) îşi mențin nivelul de influență asupra ratei CCO, o excepție fiind factorul de personalitate Cs (tabelul 3). Factorii de personalitate explică variabilitatea $\mathrm{CCO}$ cu 18 $\%$ asupra CCO-A $\left(\mathrm{R}^{2}=.18, \mathrm{p}<.00\right)$ respectiv $10 \%$ din variabilitatea CCO-E $\left(\mathrm{R}^{2}=.10, \mathrm{p}<.00\right)$.

Vizavi de contribuția LTf acesta explică CCO cu $4 \%$ în ambele cazuri, varianța explicată $\Delta \mathrm{R}^{2}$ fiind de .04 , iar $\mathrm{F}$ schimbare este 5.12 şi respectiv 2.04 , semnificativ la $p<.05$ (tabelul 3).
În ceea ce priveşte $L T z$ acesta prezice nesemnificativ variabilitatea $\mathrm{CCO}$ în cazul ambelor tipuri de comportamente prosociale (CCO-A : $\Delta R^{2}=.004, p>.05 ; \beta=.06 ; p>.05$; şi respectiv CCO-E : $\Delta R^{2}=.01, p>.05 ; \beta=.10$; p>.05) (tabelul 3).

Referitor la relația dintre LLf şi CCO, conform datelor noastre LLf nu ar avea o influență semnificativă asupra ratei manifestării ambelor tipuri de CCO (CCO-A: $\beta=.003 ; p>.05$ şi respectiv CCO-E: $\beta=.05 ; p>.05)$.

În consecință, ipotezele nule conform cărora LTz şi LLf nu au nici un impact asupra CCO, nu vor fi respinse.

În cele ce urmează, se va analiza în ce măsură tipul de Leadership are impact asupra nivelului de ES, SatL, şi asupra Ef sau a măsurii în care subalternii percep managerii ca fiind sau nu eficienți în funcție de stilul de conducere pe care aceştia din urmă îl adoptă.

Tabel 4. Estimarea ES, SatL şi Ef pe baza predictorului Leadership

\begin{tabular}{|c|c|c|c|c|c|c|c|c|c|}
\hline \multirow[b]{2}{*}{ Variabile } & \multicolumn{3}{|c|}{ Leadereship şi ES } & \multicolumn{3}{|c|}{ "Leadership şi SatL } & \multicolumn{3}{|c|}{ Leadership şi Ef } \\
\hline & $\mathbf{R}^{2}$ & $\Delta \mathbf{R}^{2}$ & $\beta$ & $\mathbf{R}^{2}$ & $\Delta \mathrm{R}^{2}$ & $\beta$ & $\mathbf{R}^{2}$ & $\Delta \mathbf{R}^{2}$ & $\beta$ \\
\hline $\begin{array}{l}\text { Pasul I } \\
\text { LLF }\end{array}$ & $.35^{\star \star}$ & $.35 * *$ & $-.59^{\star \star}$ & $.44^{\star \star}$ & $.44^{* *}$ & $-.66^{\star *}$ & $.37^{* *}$ & $.37^{\star *}$ & $-.61^{* *}$ \\
\hline $\begin{array}{l}\text { Pasul II } \\
L L F \\
L T z\end{array}$ & $.42^{* *}$ & $.07^{*}$ & $\begin{array}{l}-.57^{\star \star} \\
.26^{\star \star} \\
\end{array}$ & $.57^{* *}$ & $.13^{\star *}$ & $\begin{array}{l}-.63^{\star *} \\
.35^{\star *}\end{array}$ & $.45^{\star \star}$ & $.07^{\star}$ & $\begin{array}{l}-.59^{\star *} \\
26 .{ }^{* *}\end{array}$ \\
\hline $\begin{array}{l}\text { Pasul III } \\
L L F \\
L T z \\
L T f \\
\end{array}$ & $.65^{\star *}$ & $.23^{\star \star}$ & $\begin{array}{l}-.06 \\
-.07 \\
.79^{* \star} \\
\end{array}$ & $.73^{\star \star}$ & $.16^{\star \star}$ & $\begin{array}{l}-.20^{\star \star} \\
.07 \\
.67^{\star \star} \\
\end{array}$ & $.58^{\star \star}$ & $.13^{*}$ & $\begin{array}{l}-.20^{\star} \\
.09 \\
.61^{\star *} \\
\end{array}$ \\
\hline $\begin{array}{l}\text { Pasul 1: } \\
\text { Pasul II: F } \\
\text { Pasul III: F }\end{array}$ & $\begin{array}{l}1,136)= \\
135)= \\
134)=\end{array}$ & $\begin{array}{l}77 ; p<.00 \\
31 ; p<.00 \\
6 ; p<.00\end{array}$ & III & $\begin{array}{l}F(1,13 \\
F(2,13 \\
(3,134)\end{array}$ & $\begin{array}{l}=108.8 \\
=89.6 ; \\
124.2, p\end{array}$ & $\begin{array}{l}<.00 \\
<.00 \\
.00\end{array}$ & & $\begin{aligned} & F(1, \\
= & (2,13 \\
= & (3,13\end{aligned}$ & $\begin{array}{l}=82,66 ; p<.00 \\
55.1 ; p<.00 \\
3.41 ; p<.00\end{array}$ \\
\hline
\end{tabular}

În tabelul 4 avem modele de regresie multiliniară în 3 paşi. Suntem interesați în special impactul stilului de LTf, şi modul în care interacțiunea dintre cei trei subfactori prezic evoluția variabilelor criteriu (ES, SatL şi Ef).

În primul model $\mathrm{s}$-a testat valoarea predictivă a Leadershipului asupra ES.

În primul pas al modelului de regresie s-a introdus LLF, vedem că acesta explică $35 \%$ din cauzele pentru care subalternii manifestă ES, acesta este un impact puternic semnificativ, $\mathrm{R}^{2}$ fiind de .35 sau de $35 \%$ care este semnificativ la $p<.00$, în consecință prezența unui LLf prezice în sens negativ manifestarea acestui tip de comportament din partea subalternilor, deoarece coeficientul $\beta$ este negativ $(-.59$, semnificativ la $p<.00)$.

În pasul doi al modelului de regresie, analizând influența LLf şi interacțiunea acestuia cu LTz asupra ES, putem menționa că modelul de regresie îşi îmbunătățeşte nivelul de predictivitate asupra ES cu $7 \%$ (F schimbare $(1,135)$ fiind de 16.3 ; semnificativ la $\mathrm{p}<.00) \mathrm{LTz}$ spre deosebire de LLf are un impact stimulator asupra criteriului.

În pasul trei al modelului constatăm următorul fapt: primii doi predictori LTz şi LTf, pierd din valoarea predictivă, atunci când interacționează cu LTf, deoarece sunt nesemnificativi statistic $(\beta=-.06, \quad p>.05 ; \quad$ şi 
respectiv $\beta=-.07, p>.05)$ spre deosebire cel de al treilea factor LTf $(\beta=.79, \quad p<.00)$, care îmbunătățeşte eficiența modelului de regresie în a prezice ES cu $23 \%\left(\Delta \mathrm{R}^{2}=.23, \mathrm{~F}\right.$ schimbare $(1,134)=89.2, \quad p<.00) . \quad$ Aceasta pierdere din semnificație a factorilor LTz şi LLf ne oferă informații vizavi de faptul că aşa cum se stipulează în teoria transformațională, LTf se formează pe baza LTz, iar LLf mai este numit şi nonleadership. $\mathrm{Ca}$ urmare, variabilitatea criteriului ES este explicată în proporție de $23 \%$ de factorul Leadership în general. Aceste rezultate confirmă ipoteza 3, conform căreia LTf contribuie într-o mai mare măsură la explicarea evoluției ES decât celelalte două stiluri de leadership.

În ceea ce priveşte tipul de leadership şi SatL, din tabelul de mai sus observăm următoarele: LLf explică $44 \%$ din evoluția criteriului. LTz aduce un plus de explicație, când interacționează cu LLf, de $7 \%\left(\Delta \mathrm{R}^{2}=.13\right.$, F schimbare $(1,135)$ ia valoarea 39,5 ; puternic semnificativă la $p<.00$ ), iar LTf prezice evoluția variabilei SatL cu 16\%, (F schimbare $(1,134)=83.6 ; p<.00$ ) (tabel 4). În pasul III al modelului LTz în interacțiune cu LTf şi LLf este nesemnificativ statistic $(\beta=.07, p>.05)$. Ca urmare, SatL este prezisă de Leadership în proporție de $16 \%$.

De asemenea, mărimea efectului este de $73 \%\left(R^{2}=.73, p<.00\right)$ atunci când adăugăm la modelul de regresie şi LTf, care este superior celor obținuți în pasul unul şi doi al modelelor de regresie $\left(R^{2}=.44, \quad p<.00\right.$; respectiv $\left.R^{2}=.57, p<.00\right)$.

În consecință, manifestarea comportamentelor specifice LTf prezic într-o mai mare măsură SatL a angajaților decât manifestarea celor tipice LTz sau LLf. LLf conform rezultatelor din tabel prezice în sens negativ SatL $(\beta=-.66, p<.00)$.

Vizavi de stilul de leadership şi Ef, constatăm următoarele: LLF explică $37 \%$ din evoluția criteriului, $(\beta=-.61, p<.00)$, coeficientul beta având semnul minus. Atunci când se mai adaugă predictorul LTz obținem un plus de explicație a modelului de regresie de $7 \%\left(\Delta R^{2}\right.$ $=.07, p<.01 ; \beta=.26, p<.01$ ), observăm că $F$ schimbare este semnificativ $F(1,135)=17.5$; $\mathrm{p}<.00$.

În pasul trei al modelului $s$-a adăugat predictorul LTf $(\beta=.61$, la $p<.00)$, acesta explică $13 \%$ din variabilitatea criteriului (F schimbare este semnificativ statistic: $F$ $(1,134)=44.4 ; p<.00)$. Ceea ce demonstrează că Leadershipul în general explică $13 \%$ din Ef managerului percepută de către subalterni.
În concluzie vizavi de predictorul $L T f$, din modelele de regresie reiese că acesta are rolul cel mai semnificativ în prezicerea ES, SatL şi Ef. Prin urmare ipotezele ştiințifice 3, 4, şi 5 vor fi acceptate.

\section{Discuții şi limite ale cercetării}

Din calculele statistice analizate anterior s-a putut observa că tipul de Leadership are într-adevăr un rol considerabil în prezicerea evoluției comportamentelor deviante, prosociale, satisfacției cu superiorul, eficienței procesului de leadership şi a măsurii în care subalternii sunt dispuşi sa depună efort suplimentar în realizarea sarcinilor, cei mai puternici predictori în acest sens fiind Leadershipul Transformativ şi cel LaissezFaire. Leadershipul Tranzacțional s-a dovedit a avea o influență instabilă asupra evoluției criteriilor mai sus menționate.

Astfel, putem afirma că în mare parte ipotezele de cercetare ştiințifice stabilite la începutul cercetării se confirmă, cele nule putând fi respinse.

Într-adevăr un leader Transformativ este benefic pentru organizație, deoarece acesta joacă rolul de model cu care subalternii se identifică şi dovedeşte un interes veritabil pentru problemele cu care se confruntă angajații, ceea ce duce la inhibarea manifestării de către angajați a comportamentelor contraproductive organizaționale atât cele orientate spre individ cât şi cele orientate spre organizație.

De asemenea, prin moralitatea şi grija manifestată vizavi de subalterni, superiorul încurajează manifestarea comportamentelor cetățeneşti organizaționale de ajutor. Distanța față de putere mica în organizațiile unde superiorii manifestă un astfel de leadership şi atmosfera mai degrabă de colaborare decât de concurență, sunt stimulative pentru manifestarea comportamentelor prosociale de exprimare, aceasta şi datorită faptului că subalternii se identifică nu numai cu managerul ci într-o oarecare măsură şi cu organizația.

În schimb, un stil de leadership care manifestă predominant comportamente de iresponsabilitate, evitarea luării deciziilor, indiferență față de trebuințele subordonaților, etc., va stimula apariția comportamentelor contraproductive din partea angajaților şi va duce la o diminuare a celor prosociale în mediul organizațional.

Contrar ipotezelor stabilite la începutul cercetării, Leadershipul tranzacțional pare a 
avea un efect neînsemnat asupra comportamentelor manifestate de către subalterni la locul de munca, atât în cazul celor de tip deviant cât şi în cazul celor prosociale. Acest lucru însă s-ar putea datora coeficientului de consistență internă a scalei Leadership Tranzacțional care este destul de redus $(\alpha=.53)$, şi care are ca efecte rezultate inconsistente dintre $\mathrm{LTz}$ şi variabilele criteriu incluse în studiul de față, rezultate similare au obținut şi alți cercetători în studii anterioare (Judge \& Piccolo, 2004).

O altă explicație posibilă ar fi că efectele $L T z$ în cazul de față sunt ceva mai subtile, decât ale celorlalte tipuri de leadership. $\mathrm{Ne}$ referim aici la faptul că, majoritatea organizațiilor în care s-a realizat studiul sunt de tip privat, iar comparativ cu alte organizații de stat $\mathrm{cu}$ acelaşi profil remunerarea este satisfăcătoare, ca rezultat $s$-ar putea ca acest aspect să fie mai puțin important. De asemenea, subalternii ar putea fi suficient de experimentați în sarcinile de muncă, în consecință aceştia ar avea nevoie de mai puțină supraveghere din partea managerilor.

De asemenea, Leaderhipul Transformativ se formează pe baza celui Tranzacțional. Acesta din urmă, integrează funcțiile de bază pe care le are de realizat un manager. Leadershipul Transformativ are întradevăr specifice anumite comportamente care îmbunătățeşte nivelul de eficiență al unui manager, având un rol major în satisfacția angajaților cu superiorul şi cu munca (Judge \& Piccolo, 2004, Judge et al., 2004), dar acesta nu este suficient pentru ca organizația sa lucreze la parametri normali sau chiar să supraviețuiască. În această ordine de idei, putem oferi motivații inspiraționale, considerații individualizate, etc., la nesfârşit, dacă nu vom oferi recompense materiale după merit, feedback obiectiv vizavi de îndeplinirea sarcinilor, supraveghearea suficientă a mersului producției, controlul calității, etc., rezultatele vor fi departe de cele aşteptate, mai ales în cazul unor corporații mari, unde anonimatul este mai specific.

$\mathrm{Ca}$ urmare, manifestarea stilului Tranzacțional este o condiție absolut necesară pentru supraviețuirea unei organizației dar nu şi suficientă pentru ca această să se dezvolte, să se adapteze cu succes la mediul extern, etc.

În ceea ce priveşte, celelalte 3 variabile dependente şi anume Efortul suplimentar, eficiență şi Satisfacția cu managerul, în acord, cu ipotezele de la începutul cercetării, LTf are un impact mai puternic în comparație cu celelalte două tipuri de leadership (LLf şi LTz).

Mai specific, subalternii ce beneficiază de un leadership transformativ manifestă o disponibilitate mai mare de a depune efort suplimentar în realizarea sarcinilor (sau dincolo de expectanțele managerului), decât în cazul angajaților unde managerul manifestă predominant comportamente laissez-faire sau specifice leadershipului tranzacțional. Totuşi nu trebuie uitat faptul că aceasta nu este o măsurătoare obiectivă, ca urmare ar putea fi interpretată ca disponibilitatea subalternilor de a depune eforturi suplimentare în realizarea obiectivelor organizaționale, iar tipul de Leadership ar influența această disponibilitate. Subalternii unor astfel de superiori sunt mai mulțumiți de comportamentul şefului lor, lucru care s-a demonstrat şi în alte studii (Pearce \& Sims, 2002; Bono, et al., 2007; Bono \& Judge, 2003; etc.). De asemenea, managerii ce manifestă LTf sunt percepuți ca fiind mai eficienți decât acei superiori ce manifestă $L T z$ sau LLf. Aceste rezultate sunt în acord cu rezultatele din cercetări anterioare (Bono et al., 2007).

Factorii de personalitate, în studiul de față, au fost introduşi cu scopul de a le controla rolul acestora asupra variabilelor criteriu. Conform rezultatelor noastre aceştia au un rol semnificativ în prezicerea evoluției CCO şi CCp, s-au remarcat în special factorii Agreabilitate şi Stabilitate Emoțională.

Nivelul de Stabilitate Emoțională a subalternilor $\mathrm{s}$-a dovedit un predictor puternic pentru comportamentele deviante la locul de muncă atât cele orientate asupra indivizilor cât şi cele orientate asupra organizației. $\mathrm{Ca}$ urmare un nivel ridicat al instabilității emoționale determină într-o oarecare măsură devianța de la locul de muncă. Astfel de subalterni sunt mai înclinați spre a se comporta nepoliticos sau a-şi jigni colegii sau dacă este cazul - clienții, precum şi faptul că aceştia sunt mai predispuşi a manifesta comportamente dăunătoare însăşi organizației (tergiversarea îndeplinirii sarcinilor, furturi, întârzieri, etc.). Factorul Agreabilitate explică şi el într-o oarecare măsură astfel de comportamente, doar că ceva mai puțin, în schimb acesta din urmă are un rol considerabil în explicarea comportamentelor prosociale din mediul organizațional. $\mathrm{Ca}$ urmare angajații ce manifestă scoruri înalte la acest nivel sunt predispuşi spre a manifesta într-o mai mare măsură comportamente civic participative 
decât cei ce obțin scoruri mai joase la această trăsătură. Factorul Conştiinciozitate are un impact însemnat asupra comportamentelor civic- participative de exprimare şi parțial asupra comportamentelor deviante orientate asupra organizației. Altfel spus, subalternii ce manifestă scoruri înalte la această trăsătură au tendința de a manifesta comportamente prosociale de exprimare, în schimb un scor redus la acest factor determină comportamente deviante orientate asupra organizatiei.

$\mathrm{Ca}$ şi limite ale cercetării putem menționa faptul că procedura de eşantionare este neprobabilistă, deoarece alegerea participanților la studiu s-a făcut pe bază de voluntariat (Trochim, 2004).

De asemenea, dat fiind faptul că datele au fost culese prin intermediul chestionarului, nu este exclus ca rezultatele să fie distorsionate datorită celor trei mari dezavantaje pe care le implică utilizarea chestionarelor, şi anume: dezirabilitate socială sau opusul acesteia (încercarea participanților de a se pune într-o lumină mai puțin favorabilă, față de cercetător) precum şi răspunsurile date la întâmplare.

Răspunsurile subordonaților la chestionare au fost strict confidențiale şi anonime, deci nu se poate afirma că rezultatele au fost obediente față de superiori.

\section{Concluzii şi direcții noi de cercetare}

În concluzie putem afirma că în mare măsură, ipotezele stabilite la începutul cercetării se confirmă.

Astfel teoria leadership-ului transformațional explică într-o proporție semnificativă comportamentele cetățeneşti organizaționale şi cele contraproductive manifestate de către subalterni. Factorul leadership transformațional contribuie cel mai mult la explicarea variabilității criteriilor.

Leadershipul laissez-faire are o influență pozitivă asupra manifestării comportamentelor contraproductive şi negativă asupra celor cetățeneşti organizaționale.

În plus, angajații ce beneficiază de un stil de leadership transformativ sunt mai satisfăcuți de relația lor cu superiorul, sunt mai dispuşi de a manifesta efort suplimentar pentru realizarea sarcinilor, şi percep managerul ca fiind mai eficient în atingerea obiectivelor organizaționale. Acestea sunt în acord cu rezultatele din studiilor anterioare pe teoria transformațională, de către alți cercetători
(Keller, 2006; Kark, et al., 2003; Bass \& Avolio, 1999, etc.).

Factorii de personalitate explică într-o proporție foarte semnificativă comportamentele manifestate la locul de muncă. Astfel dintre cei trei mari factori de personalitate introduşi ca variabile de control în cercetare, doi dintre aceştia (Agreabilitate şi Stabilitate Emoțională) explică consistent manifestarea comportamentelor contraproductive şi cetățeneşti organizaționale.

Ca şi direcții ulterioare de cercetare putem sugera studierea măsurii în care emoțiile mediază relația dintre leadershipul transformațional şi comportamentele manifestate în mediul organizațional din partea angajaților, în speță cele deviante şi prosociale, deoarece 0 altă cauză a comportamentelor deviante şi prosociale, aşa cum s-a afirmat în mai multe cercetări, sunt tipurile de emoții manifestate de către subalterni (Offerman şi Hellman,1996). De asemenea, modul în care tipul emoțiilor prezente la locul de muncă sunt influențate de superiori sau predominanța unui anumit tip de leadership (Cobia \& Boes, 2000; Bono, et al., 2007; Bruk-Lee \& Spector, 2006).

\section{Bibliografie}

Arnold, K.A., Turner, N., Barling, J., Kelloway, K.E., \& McKee, C. (2007). Transformational Leadership and Psychological Well-Being: The Mediating Role of Meaningful Work. Journal of Occupational and Health Psychology. 12,3, 193-203.

Avolio, B.I., \& Bass, B.M. (1999). Re-examining the componenets of transformational and transactional leadership using the multifactor leadership questionnaire. Journal of Occupational and Organizational Psychology. 72, 1, 441-462.

Avolio, B., Bass, B., lliescu, D., Beldean, F., \& Sîntion, F. (2007). Technical and interpretative manual of the $M L Q$ (Multifactor Leadership Questionnaire) in Romania. Cluj-Napoca: Odiseea.

Bachrach, D.G., Powell, B.C., Bendoly, E., \& Richey, R.G., (2006). Organizational Citizenship Behavior and Performance Evaluations: Exploring the Impact of Task Interdependence Journal of Applied Psychology. 91, 1, 193-201.

Bass B. M., Jung D.I., Avolio B.J., \& Berson, Y. (2003). Predicting Unit Performance by Assessing Transformational and 
Transactional Leadership. Journal of Applied Psychology, 88, 2, 207-218.

Bennett, R.J., \& Robinson, S.L. (2000). Development of a Measure of Workplace Deviance. Journal of Applied Psychology. 85,3, 349-360.

Bono, J.E., Foldes, H.J., Vinson, G., \& Muros, J.P. (2007). Workplace emotionas: the role of supervision and leadership. Journal of Applied Psychology, 92, 5, 1357-1367.

Bono, J.E., \& Judge, T.A. (2004). Personality and Transformational Leadership and Transactional Leadership, a Meta-Analysis. Journal of Applied Psychology. 89, 5, 901910.

Bono, J.E., \& Judge, T.A. (2003). Self-concordance at work : toward understanding motivational effects of transformational leaders. Academy of Management Journal, 46, 554571.

Borman, W. C., \& Motowidlo, S. J. (1997). Task performance and contextual performance: The meaning for personnel selection research. Human Performance, 10, 99-109.

Bruk-Lee, V., \& Spector, P.E. (2006). The Social Stressors-Counterproductive Work Behaviors Link: Are Conflicts With Supervisors and Coworkers the Same? Journal of Occupational Health Psychology, 2006, 11, 2, 145-156.

Bycio, P., Hackett, R.D., \& Allen J.S. (1995). Further Assessments of Bass's (1985). Conceptualization of Transactional and Transformational Leadership. Journal of Applied Psychology. 80, 4, 468-478.

Caprara, G. V., Barbaranelli, C., Borgogni, L., Pitariu, H. D., Vercellino, D., \& Iliescu, D. (2008). Manual tehnic si interpretativ al BFQ pentru Romania. Cluj-Napoca: Odiseea.

Chemers M.M. (2000). Leadership Research an Theory: A Functional Integration. Group Dynamics: Theory, Research, and Practice, 4, 1, 27-43.

Cobia, D. C, \& Boes, S. R. (2000). Professional disclosure statements and formal plans for supervision: Two strategies for minimizing the risk of ethical conflicts in post-master's supervision. Journal of Counseling and Development, 78, 293-296.

Colbert, A.E., Mount, M.K., Harter, J.K., Witt, L.A., \& Barrick, M.R. (2004). Interactive Effects of Personality and Perceptions of the Work Situation onWorkplace Deviance. Journal of Applied Psychology, 89, 4, 599-609.

Dalal, R.S. (2005). A Meta-Analysis of the Relationship Between Organizational Citizenship Behavior and Counterproductive
Work Behavior. Journal of Applied Psychology, 90, 6, 1241-1255.

Den Hartog, D.N., Van Muijen, J.J., \& Koopman, P.L. (1997). Transactional versus Transformational leadership: an analysis of the MLQ. Journal of Occupational and Organizational Psychology. 1, 2, 19-34.

Dierendonck, D., Haynes, C., Borrill, C., \& Stride, C. (2004). Leadership Behavior and Subordonate Well-Being. Journal of Occupational Health Psychology. 9(2), 165175.

Dilchert, S., Ones, D.S., Davis, R.D., \& Rostow, C.D., (2007). Cognitive Ability Predicts Objectively Measured Counterproductive Work Behaviors. Journal of Applied Psychology, 92, 3, 616-627.

Epitropaki, O., \& Martin R. (2005) From Ideal to Real: A Longitudinal Study of the Role of Implicit Leadership Theories on LeaderMember Exchanges and Employee Outcomes. Journal of Applied Psychology. 90, 4, $659-676$.

Fuqua, D.R., \& Newman (2005). Integrating Structural and Behavioral Leadership Strategies. Consulting Psychology Journal: Practice and Research, 57, 2, 126-132.

Hogan, R., \& Kaiser, R.B. (2005). What we know about Leadership. Review of central Psychology. 9,2, 169-180.

Howell, J.M., \& Avolio, B.J. (1993). Transformational Leadership, Transactional Leadership, Locus of Control and Support for Innovation: Key Predoctors of Consolidated - Business Unit Performance. Journal of Applied Psychology, 78, 6, 891-902.

Hurz, G. M., \& Donovan, J. J. (2000). Personality and job performance: The Big Five revisited. Journal of Applied Psychology, 85, 869-879.

Jackson C.L. \& LePine J.A. (2003) Peer Responses to a Team's Weakest Link: A Test and Extension of LePine and Van Dyne's Model. Journal of Applied Psychology, 88, 3, 459-475.

Judge, T.A., \& Piccolo, R.F. (2004). Transformational and Transactional Leadership A Meta-Analytic Test of Their Relative Validity. Journal of Applied Psychology. 89, 5, 755-768.

Judge, T.A., Piccolo, R.F., \& llies, R. (2004). The Forgotten Ones? The Validity of Consideration and Initiating Structure in Leadership Research. Journal of Applied Psychology. 89(1), 36-51. 
Kara, A.A., Turner, N., Barling J., Kelloway, E.K., \& McKee, M. (2007). Tranformational leadership and psychological well-being: the mediating role of meaningful work. Journal of Occupational Health Psychology, 12,3, 193-203.

Kark, R., Shamir, B., \& Chen, G. (2003). The Two Facets of Transformational Leadership: Empowerment and Dependency. Journal of Applied Psychology, 88, 2, 246-255.

Keller, R.T. (2006). Transformational Leadership, Initiating Structure, and Substitutes for Leadership: A Longitudinal Study of Research and Development Project Team Performance. Journal of Applied Psychology. 91, 1, 202-210.

Kelloway, E., Mullen, J., \& Francis, L. (2006). Divergent Effects of Transformational and Passive Leadership on Employee Safety. Journal of Occupational Health Psychology. 11, 1, 76-86.

Levine, \& Xu, Xian, (2005). Development and validation of the State-Trait Emotion Measure (STEM). Paper presented at the 20th Annual Conference of the Society Industrial and Organizational Psychology, April.

Liao, H., \& Chuang, A. (2007). Transforming service employees and climate: a multilevel, multisource examination of transformational leadership in building long-term service relationships. Journal of Applied Psychology, 92, 4, 1006-1019.

Lim, B.C., \& Ployhart, R.E. (2004). Transformational Leadership Relation to the Five/Factor Model and Team Performance in Typical and Maximum Context. Journal of Applied Psychology. 89, 4, 610-621.

Lowe, K.B., Kroeck, K.G., \& Sivasubramanian, N. (1996) Effectiveness corelates of transformation and trasational leadership: A meta-analytic review of the MLQ literature. Leadership Quarterly, 7, 1, 385425.

McCarthy Veach, P. (2001). Conflict and Counterproductivity in Supervision-When Relationships Are Less Than Ideal: Comment on Nelson and Friedlander (2001). and Gray et al. (2001) Journal of Counseling Psychology, 48, 4, 396-400.

Moorman, R. (1991). Relationship Between Organizational Justice and Organizational Citizenship Behaviors: Do Fairness Perceptions Influence Employee Citizenship? Journal of Applied Psychology, 76, 6, 845-855.
Northouse, P.G. (2001). Leadership: Theory and practice. California: Saje Publication.

Offerman, L.R., \& Hellman, P.S. (1996). Leadership behavior and subordonate stress. A $360^{\circ}$ view. Journal of Occupational Health Psychology, 1, 382390.

Pearce, C.L., \& Sims, H.P.jr. (2002). Vertical Versus Shared Leadership as Predictors of the Effectiveness of Change Management Teams: An Examination of Aversive, Directive, Transactional, Transformational and Empowering Leader Behaviors. Group Dynamics: Theory, Research, and Practice, 6, 2, 172-197.

Podsakoff, P. M., MacKenzie, S. B., Paine, J. B., \& Bachrach, D. G. (2000). Organizational citizenship behaviors: A critical review of the theoretical and empirical literature and suggestions for future research. Journal of Management, 26, 1, 513-561.

Rioux, S.M., \& Penner, L.A. (2001). The causes of organizational citizenship behavior: A motivational analysis. Journal of Applied Psychology. 86, 6, 1306-1314.

Rotundo, M., \& Sackett, P.R. (2002). The Relative Importance of Task, Citizenship, and Counterproductive Performance to Global Ratings of Job Performance: A PolicyCapturing Approach, Journal of Applied Psychology, 87, 1, 66-80.

Salgado, J.F. (2002). The Big Five Personality Dimensions and Counterproductive Behaviors International Journal of Selection and Assessment, 10, 1, 117-125

Sava, F., (2004). Analiza datelor în cercetarea psihologică. Metode statistice complementare. Cluj-Napoca: Editura ASCR.

Sîntion, F., \& Iliescu, D. (2007). Teoriile leadershipului. Anexa teoretica la manualul MLQ. Cluj-Napoca: Odiseea.

Schaubroeck, J., Lam, S.S., \& Cha, S.E. (2007). Embracing Transformational Leadership: Team Values and the Impact of Leader Behavior on Team Performance. Journal of Applied Psychology, 92, 4, 1020-1030.

Sosik, J. J., Avolio, B.J., \& Kahai, S.S. (1997). Effects of leadeship Styles and Anonymity on Group Potency and Effectiveness in a Group Decision Support System Environment. Journal of Applied Psychology, 82, 1, 89-103.

Spector, P. E., \& Fox, S. (2002). An emotioncentered model of voluntary work behavior: Some parallels between counterproductive work behavior and organizational 
citizenship behavior. Human Resource Management Review, 12, 269-292.

Sy, T., Cote, S., \& Saavedra, R.(2005). The contagious leader: impact of the leader's mood of group members, group affective tone, and group processes. Journal of Applied Psychology, 90, 2, 295-305.

Tepper, B.J. (2000) Consequences of abusive supervision. Academy of Management Journal, 43, 178-190.

Tepper, B.J. Lockhart, D., \& Hoobler, J. (2001). Justice, citizenship, and role definition effects. Journal of Applied Psychology. 86, 4, 789-796.
Trochim, W.M. (2004). Sampling, în Trochim W.M. Research Methods Knowledge Base. Cornell University; găsit la adresa: http://www.socialresearchmethods.net/kb/s ampling.htm.

Van Dyne, L., \& LePine, J.A. (1998). Helping and voice extra-role behavior: Evidence of construct and predictive validity. Academy of Management Journal, 41, 108-119.

Viswesvaran, C., \& Ones, D.S. (2000). Perspectives on models of job performance. International Journal of Selection and Assessment, 8, 216-226.

\section{D\&D Consultants, Bucureşti \\ www.ddconsultants.ro}

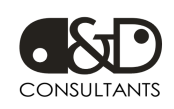

Instrumente psihometrice publicate de D\&D Consultants/TestCentral

CPITM (California Psychological Inventory (462, 434, 260))

NPQTM (Nonverbal Personality Questionnaire)

FFNPQTM (Five-Factor Nonverbal Personality Questionnaire)

SWSTM (Survey of Work Styles)

STAXI-2 ${ }^{\text {TM }}$ (State-Trait Anger Expression Inventory)

FPITM (Freiburg Personlichkeitsinventar (Formele G şi R))

LSI $^{\mathrm{TM}}$ (Learning Styles Inventory)

MLQTM (Multifactor Leadership Questionnaire (Forma 5X))

STAI $^{\text {TM }}$ (State-Trait Anxiety Inventory)

STAICTM (State-Trait Anxiety Inventory for Children)

JVISTM (Jackson Vocational Interest Survey)

AMITM (Achievement Motivation Inventory)

FJAS $^{\text {TM }}$ (Fleishman Job Analysis Survey)

Instrumente psihometrice în curs de apariție:

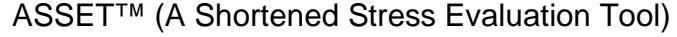

$E P Q^{T M}-R$ (Eysenck Personality Questionnaire, Revised)

IVETM (Eysenck's Impulsiveness Questionnaire)

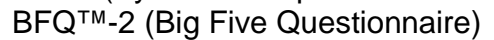

$B A^{T M}$ (Big Five Adjectives)

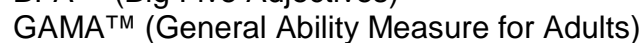

MAB $^{\text {TM }}$-II (Multidimensional Aptitude Battery)

NEO-PI-R ${ }^{\mathrm{TM}}$ (Revised NEO Personality Inventory)

BASC-2 ${ }^{\text {TM }}$ (Behaviour Assessment System for Children, Second Edition)

MSCEITTM (Mayer Salovey Caruso Emotional Intelligence Test)

EO-ITM (Emotional Quotient Inventory)

TEDE6 ${ }^{\text {TM }}$ (Test d'évaluation dynamique de l'éducabilité)

$\mathrm{DDDI}^{\mathrm{TM}}$ (Dula Dangerous Driving Index) 